\title{
Femur başı avasküler nekrozu tedavisinde güncel literatür (ne diyor?)
}

\author{
Current literature on the treatment of avascular necrosis of the femoral head \\ (what it says?) \\ Olcay Güler ${ }^{1}$, İrfan Esenkaya ${ }^{2}$
}

\begin{abstract}
${ }^{1}$ Altınbaş Üniversitesi Tıp Fakültesi, Ortopedi ve Travmatoloji Anabilim Dalı, İstanbul; Bahçelievler Medicalpark Hastanesi, İstanbul ${ }^{2}$ Ortopedi ve Travmatoloji Uzmanı, Emekli Öğretim Üyesi; SANTE Tıp Merkezi, Ortopedi ve Travmatoloji Bölümü, Kalamış, İstanbul
\end{abstract}

\begin{abstract}
Femur başı avasküler nekrozu (FBAVN), özellikle genç erişkinleri etkilemekte ve tedavi edilmediği takdirde kalça ekleminde ilerleyici bozulmalara sebep olabilmektedir. FBAVN tedavi planlamasında; hastanın yaşı, hastalığın etiyolojisi, lezyon boyutu, lezyonun yerleşimi, femur başı yuvarlaklığının durumu ve kalça eklemindeki artrozik değişiklikler değerlendirilmelidir. Hastalığın tedavisine karar verirken hekimi yönlendiren en önemli parametre femur başı yuvarlaklığının durumudur. Erken evre femur başında çökme olmadığı durumlarda tedavi planlamasında, kalça eklemini veya femur başını koruyucu tedaviler önerilmektedir. Femur başı koruyucu cerrahi tedavisinde amaç, nekrotik dokunun ortadan kaldırılarak defektli bölgede yeniden kemik oluşumunun sağlanması prensibine dayanmaktadır. Femur başını koruyucu tedavi seçenekleri arasında kor (core) dekompresyon, damarlı ya da damarsız kemik grefti, proksimal femoral osteotomiler ile mezenkimal veya kemik iliği kaynaklı kök hücre uygulamaları yer almaktadır. Femur başı yuvarlaklığının kaybolduğu yani başta çökmenin ortaya çıktığı durumlarda total kalça artroplastisi en güncel seçenek olarak öne çıkmaktadır. Mevcut güncel tedavi yöntemlerine rağmen henüz FBAVN'nun optimal tedavisi mevcut değildir.
\end{abstract}

Anahtar sözcükler: femur başı; avasküler nekroz; kor dekompresyon; kemik greft; femoral osteotomi; total kalça protezi

\begin{abstract}
Avascular necrosis (AVN) of the femoral head, which may lead to progressive degenerative joint disease when left untreated, is particularly seen in young adults. Patient's age, aetiology of the disease, size and location of the lesion, sphericity of the femoral head, and degenerative changes of the femoral head should be evaluated during management approach for the AVN of the femoral head. Sphericity of the femoral head is the major determinant in the clinical decision-making process. Joint preserving treatment modalities are applied when the sphericity of the femoral head is intact. Main objective of joint preserving techniques relies on debridement of the necrotic tissue and induce a regenerative process to fulfil the osseous defect. Core decompression, vascular or avascularized bone graft, proximal femoral osteotomies, and mesenchymal or adipose tissue-originated stem cell transfer are among the joint preserving treatment modalities. However, total hip arthroplasty is the only surgical option in cases with loss of femoral head sphericity and collapsed cartilage of the femoral head. Despite of the current developments, ideal treatment method has not been established yet.
\end{abstract}

Key words: femoral head; avascular necrosis; core decompression; bone graft; femoral osteotomy; total hip arthroplasty
A vasküler nekroz (AVN) veya osteonekroz, travma veya travma dışı nedenlerle kemik dokusu kan akımının bozulmasına bağı kemik hücrelerinin ölümüyle sonuçlanan bir süreçtir. Tüm anatomik bölgeler arasında \%75,9 oranında en sık kalça eklemi tutulmaktadır. Erkekleri kadınlara göre 3 kat daha fazla etkilemektedir ve \%40-70 oranında her iki kalça tutulumu mevcuttur. ${ }^{[1]}$ FBAVN'ye tedavi yapılmadığı takdirde \%80 oranında femur başında çökme görülmektedir. ${ }^{[1,2]}$
FBAVN oluşumuna neden olan intravasküler (damar içi) kan akımının bozulmasında travmaya bağı ve/veya travma dışı etkenler sebep olabilmektedir. Travma dışı sebeplerin, FBAVN oluşumunu neden olduğunu açıklayan iki temel teori öne sürülmektedir. Birinci teorinin temel prensibi intravasküler koagülasyon (damar içi pıhtılaşma) olmakla birlikte, ikinci teori ise ekstravasküler kompresyon bağlı iskemi prensibine dayanmaktadır. Günümüzde ise genetik risk faktörlerinin yanı sıra vasküler bozukluklar ve değişen

- İletişim adresi: Doç. Dr. Olcay Güler, Altınbaş Üniversitesi, Bahçelievler Medicalpark Hastanesi, Kültür Sok., No:1, 34160 Bahçelievler, İstanbul Tel: 0532 - 7047069 e-posta: olcayguler77@gmail.com

- Geliș tarihi: 3 Eylül $2020 \quad$ Kabul tarihi: 22 Eylül 2020 

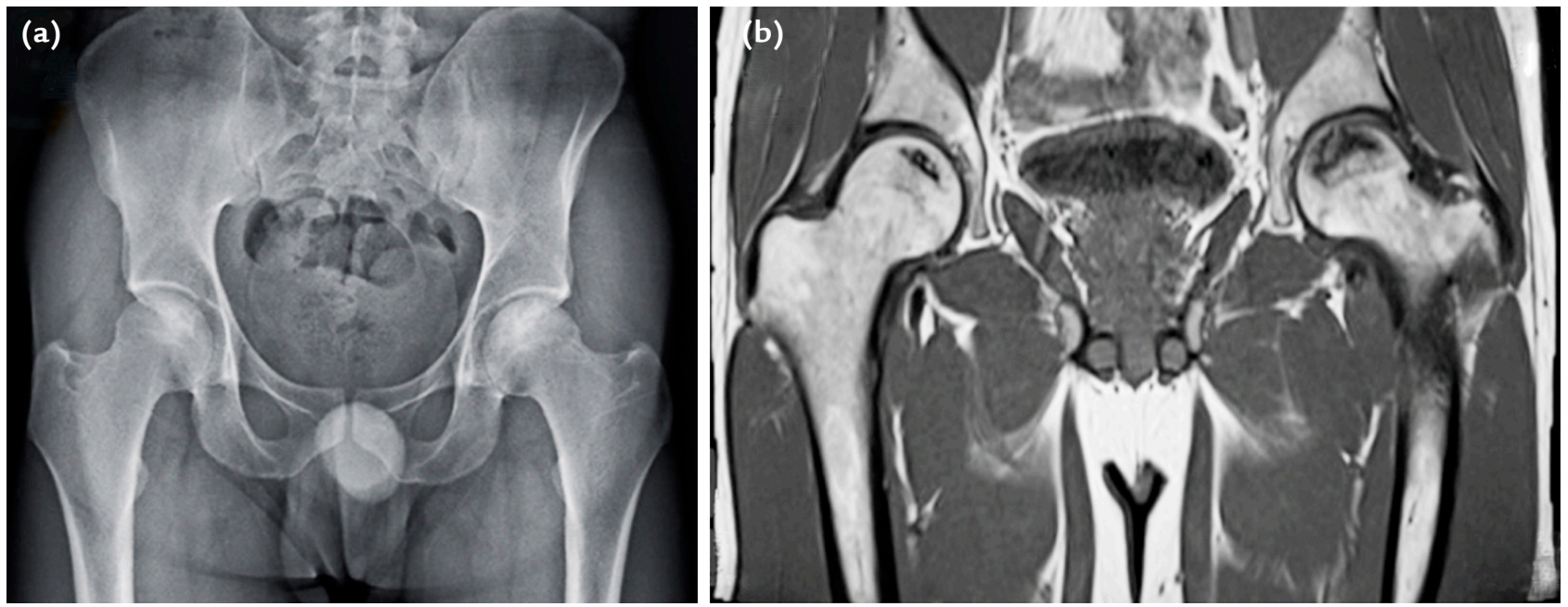

Şekil 1. a, b. Erken evre FBAVN; her iki kalça grafisi (a); her iki kalça MR koronal kesit T1 sekans görüntüsü (b).

kemik hücre fizyolojisi arasındaki etkileşimden kaynaklandığı düşünülmektedir. ${ }^{[1]}$

Ayrıca FBAVN'de en sık bilinen risk faktörleri arasında alkol alımı ve glukokortikoid kullanımı bulunmaktadır. ${ }^{[3,4]}$

\section{RADYOLOJiK INCELEME ve DEĞERLENDIRME}

FBAVN'nun teşhisinde, standart kalça grafileri, bilgisayarlı tomografi (BT), manyetik rezonans (MR) ve radyonükleotid inceleme kullanılmaktadır. Femur başında radyolusensi, skleroz ve kemik rezorpsiyonunu $M R$ ve BT en iyi gösterirken, eklemdeki dejenerasyonu en iyi standart kalça grafileri gösterir. Erken dönem FBAVN tespitinde MR daha iyi bulgu verirken, daha ileri evrede BT daha değerlidir. ${ }^{[5]}$ Pozitron emisyon tomografisi (PET) gerçek kemik fizyolojisini gösterdiği için, FBAVN'yi MR'dan daha önce tespit eder ve hastalık progresyonu (ilerlemesi) takibinde de kullanılmaktadır. ${ }^{[6]}$ MR incelemesi femur başında çökme öncesinin tespitinde altın standart olması yanında kemik ödemi ve geçici femur başı osteoporoz ayrımını da sağlamaktadır. MR incelemesinin spesifitesi (özgüllüğü) ve sensitivitesi (duyarlılığı) yaklaşık \%99 oranındadır (Şekil 1).

Kerboul ve ark. tarafından tanımlanan, sagittal ve koronal plandaki MR görüntüleri üzerinden ölçülen ve femur başındaki lezyon boyutunun gösteren nekrotik açı değerinin prognoz hakkında bilgi verdiği bilinmektedir. ${ }^{[7]}$ Başka bir çalışmada, nekrotik açı değerinin $240^{\circ}$ 'nin üzerinde olduğu tüm kalçalarda femur başında çökme görülmüş, nekrotik açı değerinin $180^{\circ}$ 'nin altında olduğu hastaların hiç birinde çökme olmamış ve nekrotik açısı $190-240^{\circ}$ arasında olan olguların yarısında çökme görülmüştür. ${ }^{[8]}$ Femur başında 2 milimetre $(\mathrm{mm})$ 'den daha fazla çökme olması kötü prognoz işaretidir. ${ }^{[1]}$ Radyolojik tetkikler tedaviye karar vermede biz ortopedi ve travmatoloji uzmanlarının başarısında anahtar rol oynayabilmektedir.

FBAVN için MR ve radyografi kullanılarak yapılan literatürde 16 farklı sınıflama tanımlamıştır. ${ }^{[1]}$ Sınıflamalarda amaç hastalık prognozu ve tedavi seçenekleri arasında karar vermeyi sağlamaktadır. Literatürdeki çalışmalarda en sık \%63 oranında Ficat ve Arlet sınıflaması, \%20 oranında Steinberg sınıflaması, \%12 oranında Osseöz Dolaşım Çalışma Derneği (ARCO) sınıflaması ve \%5 oranında ise Japon Ortopedi Derneği sınıflaması kullanılmıştır. ${ }^{[9]}$ Tüm sınıflamalar çökme öncesi dönemde konservatif tedavi ile femur başını koruyucu cerrahi arasında karar vermekte kullanılmakla birlikte günümüzde henüz ideal bir sınıflama sistemi mevcut değildir.

\section{TEDAVi}

FBAVN'de hastalığın evresine, lezyonun lokalizasyonuna, lezyonun genişliğine ve femur başının şeklini korumasına göre farklı tedavi seçenekleri mevcuttur. Özellikle femur başında çökme öncesi evrede eklem koruyucu tedavi seçenekleri ön plana çıkmaktadır. Ancak FBAVN'ye neden olan etiyolojiler ortaya konmalıdır. Özellikle orak hücreli anemiye, kortikosteroid kullanımına ve immunsupresif tedaviye bağlı oluşan FBAVN'lerde kötü prognoz riski oldukça yüksektir. ${ }^{[1,2]}$ 


\section{Konservatif Tedavi}

FBAVN'de temel tedavilerden birisi olan konservatif tedavi, erken evre ve çok küçük lezyonlarda veya cerrahi uygulanamayacak hastalarda uygulanmaktadır. Steinberg ve ARCO sınıflamasına göre evre 0 veya 1 olan olgular ideal konservatif yöntem adayıdırlar. Konservatif tedavi yöntemleri arasında yükten kurtarma, fizik tedavi rehabilitasyon, ilaç tedavisi, hiperbarik oksijen tedavisi ve ekstrakorporal şok dalga tedavisi sayılabilmektedir. ${ }^{[1]}$

Kalça eklemini yükten kurtarma yaygın ve rutin uygulanan konservatif yöntemlerden biridir. ${ }^{[1]}$ Ancak bir gözden geçirme analiz çalışmasında, tam veya kısmi yük verilen ya da hiç yük verilmeyen hastalar arasında anlamlı fark bulunmamıştır. ${ }^{[10]}$ Yazarlar yükten kurtarmakla hedeflenen femur başına gelen eklem reaksiyon kuvvetini azaltmanın hastalığın ilerlemesini engellemede bir etkisi olmadığı sonucuna varmışlardır. ${ }^{[10]}$

Son zamanlardaki ileriye dönük randomize bir çaış̧mada fizik tedavinin, kalça fonksiyonlarını geri kazanmada ve ek cerrahi işlem gereksinimini azaltmakta kor dekompresyon kadar etkin olduğu bildirilmiştir. ${ }^{[11]}$ Ancak orak hücreli anemi gibi risk grubunda olan hastalarda sonuçlar değişkenlik arz etmiş̧tir. Villa ve ark., FBAVN'li hastaların yaklaşık yarısında alkol ve steroid kullanımı olması nedeniyle diğer disiplinlerle birlikte tedavi planlaması yapılması gerektiğini belirtmişlerdir. ${ }^{[12]}$

Travmatik olmayan FBAVN tedavisinde kritik iskemi döneminden önce, endotelyal fonksiyon bozukluğunu gidermek ve tromboz oluşumunu önlemek için enoksaparin ve statin grubu ilaçlar kullanılabilir. ${ }^{[13]}$ Statin grubu ilaçlar, kemik iliğindeki yağ doku boyutunu küçültmektedir ve steroide bağlı avasküler nekrozu kanıt düzeyi yüksek çalışma olmasa da önleyebileceği düşünülmektedir. Steroid kullanan 2.881 transplantasyon hastanın incelendiği bir çalışmada, statin kullanan hastalarda FBAVN oranı \%4,4 iken, statin kullanılmayan grupta ise bu oran $\% 7$ olarak bulunmuştur ancak fark anlamlı bulunmamıştır. ${ }^{[13]}$ Enoksoparin kullanımının tromboz oluşumunu daha çok azalttı̆̆ına dair yeterli kanıt yoktur. Ancak Glueck ve ark.'nın spesifik koagülasyon bozukluğu olan Ficat evre 1 veya 2 FBAVN olan 20 hastayı inceledikleri çalışmalarında 2 yıl sonunda bir hasta hariç diğer hastalarda anlamlı iyi sonuçlar elde etmişlerdir. Sonuç olarak spesifik uygun hasta gruplarında enoksoparin tedavisinin başarılı olabileceği sonucuna varmışlardır. ${ }^{[14]}$

Kritik iskemi döneminde, osteoblastların ve osteositlerin ölümünü engellemeye yönelik farmakolojik ajanlar mevcuttur. Prostoglandin analoğu olan illoprost sistemik dilatasyon ve trombosit agregasyonunu engelleyen kemik iliği ödem tedavisinde kullanılan bir ilaçtır.
Disch ve ark., çökme öncesi dönemde olan 40 FBAVN hastasına İloprost tedavisi uygulamışlar, 25 aylık takip sonrasında hiçbir hastada çökme olmamıştır. Ayrıca hastaların klinik bulgularında belirgin iyileşme tespit edilmiştir. ${ }^{[15]}$

Erken dönem semptomatik FBAVN hastalarında hücresel iskemiyi geri çevirmek ve enflamasyonu azaltmak için hiperbarik oksijen (HBO) tedavisi uygulanabilmektedir. HBO tedavisi çözünmüş oksijen konsantrasyonunu artırarak ödemi azaltmakta ve kemik dokudaki iskemiyi azaltmaktadır. HBO hücre dışı dokulardaki diffuz oksijen miktarını artırarak iskemideki kemik hücrelerinin oksijenizasyonunu artırır. Camporesi ve ark.'nın 20 hastayı içeren randomize kontrollü çalışmalarında, HBO tedavisi uygulanan hastaların 7 yıllık klinik ve radyolojik takip sonuçlarında olumlu iyileşme görülmüş ve hastaların hepsinde semptomlar kaybolmuştur. ${ }^{[16]}$ Sekiz klinik makaleyi derleyen güncel bir çalışmada elde edilen veriler, yazarlar HBO tedavisinin FBAVN'de olumlu sonuçlar verdiği tespit etmişler ancak randomize kontrollü çalışmalara ihtiyaç olduğunu bildirilmişlerdir. ${ }^{[17]}$

Kemik rezorpsiyonu üzerine etkili olan bisfosfonatlar, kemik döngüsünü ve remodelasyonunu azaltarak örgü kemik oluşumunu engellemektedir. Bisfosfonatlar osteoklastların apoptozisini artırırken, osteoblast ve osteositlerin apoptozisini azaltığı için kemik rezorpsiyonun olduğu hastalıkların tedavisinde yaygın kullanılmaktadır. ${ }^{[1]}$ Lai ve ark.'nın 44 kalçayı içeren randomize kontrollü bir çalışmalarında FBAVN hastalarında bisfosfonat kullanımının hastalığın progresyonunu yavaşlattığı bildirilmiştir. ${ }^{[18]}$ Ancak çok merkezli 65 kalçayı içeren çift kör bir çalışmada alendronat ile plesebo arasında 2 yıl sonunda kalça protez cerrahisi yapılma oranı ve hayat kalitesi açısından anlamlı fark görülmemiştir. ${ }^{[19]}$ Başka bir randomize kontrolü çalışmada benzer şekilde kontrol grubu ile bisfosfonat kullanan grup arasında anlamlı fark bulunmamıştır. ${ }^{[12]} \mathrm{Li}$ ve ark.'nın güncel metaanalizinde FBAVN tedavisinde bisfosfonat kullanımının femur başı merkez bölge genişliğini ve baş konturunu koruduğunu bildirmişlerdir. ${ }^{[20]}$

Ekstrakorporal şok dalga (EKŞD) tedavisi, kemik morfojenik protein-2 ve damar endotel büyüme faktörlerini uyarması yanında osteoblastik aktiviteyi de artırması nedeniyle FBAVN tedavisinde kullanılmaktadır. ${ }^{[21]}$ Russo ve ark.'nın Ficat evre 1-2 FBAVN'si olan 600 'den fazla olguyu içeren güncel gözden geçirme çalışmalarında EKŞD tedavisinin etkinliğini değerlendirmişlerdir. Hastaların \%36'sında ağrının kaybolduğunu, \%43'ünde ağrının \%70'den daha fazla azaldığııı ve \%21'inde ağrıda hiç bir değişme olmadığını bildirmişlerdir. ${ }^{[21]}$ Alves ve ark.'nın literatür incelemesinde EKŞD tedavisinin etkinliğini değerlendiren yeterli ve 
uygun sayıda kanıt düzeyi yükssek çalışmalar olmadığını bildirmişlerdir. ${ }^{[22]}$

Konservatif tedavi; özellikle küçük, erken evre ve asemptomatik FBAVN hastalarında ve birden fazla konservatif tekniğin birlikte kombine edilmesi önem arz etmektedir. Ayrica eklem koruyucu cerrahi uygulanan olgularda da konservatif tekniklerde tedaviye eklenebilir.

\section{CERRAHI TEDAVI}

FBAVN'de cerrahi tedavi seçeneklerini, eklem koruyucu (femur başını koruyan) yöntemler ile kalça artroplasti yöntemleri olmak üzere ikiye ayırmak mümkündür. Femur başı subkondral kemikte çökme meydana geldiğinde kalça artroplastisi tek seçenek gibi görülmektedir.

\section{EKLEM KORUYUCU (FEMUR BAŞINI KORUYAN) TEKNIKLER}

Çökme öncesi dönemdeki genç hastalarda femur başını koruyan cerrahilerin önemi vurgulanmaktadır. Femur başını koruyan klasik cerrahiler arasında; kor dekompresyon (KD), damarlı veya damarsız kemik grefti ve proksimal femoral osteotomiler sayılabilir. Ayrıca son yıllarda mezenkimal kök hücre ile zenginleştirilmiş kemik greftleri, kemik morfojenik proteinle zenginleştirilmiş kemik greftleri ve gözenekli tantalum kullanılmaya başlamıştır. ${ }^{[1]}$

\section{Kor Dekompresyon}

Kor dekompresyon (KD), Ficat ve Arlet tarafindan tanımlanmış ve FBAVN'de çökme öncesi dönemde uygulanmaktadır. KD tedavisinde amaç, kemik içi basıncı düşürmek ve vasküler dolaşımı yeniden sağlamaktır. KD tekniği iki farklı şekilde uygulanabilir. Birincisi femur boynu ve baş içinden geçerek nekrotik alan hedeflenerek tek 8-10 milimetre $(\mathrm{mm})$ deliğin açıldığı, ikincisi ise üçten fazla 3,2 mm'lik deliğin açıldığı tekniklerdir. ${ }^{[2,23]}$

Ficat'ın orijinal çalışmasında evre 1-2 FBAVN olan 133 kalçadan oluşan serilerinde $\% 90$ oranında başarılı sonuç ve 9,5 yıllık takiplerinde hastalık progresyonunda minimal ilerleme olduğu görülmüştür.[24] 1996 yılında Mont ve ark., sadece KD uyguladıkları 1,206 olguluk serilerinde $\% 63,5$ 'luk başarı oranı bildirmişlerdir. ${ }^{[10]}$ Çalışmalar göstermektedir ki KD başarı oranları \%40-90 arasında değişmektedir. ${ }^{[25]}$

Subkondral çökmesi olmayan, küçük (femur başının \%15'inde küçük veya Kerboul açısı $<200^{\circ}$ ) veya medial lezyonlar için KD tekniği önerilmektedir. Ancak hastanın yaşı, avasküler nekroz etiyolojisi, lezyon boyut ve yerleşimi KD sonuçlarında değişkenliğe neden olmaktadır. ${ }^{[2]}$

\section{Mezenkimal veya Kemik iliği Kökenli Kök Hücre}

Hücresel tedavi, FBAVN'de erken, çökme öncesi dönemde kemik oluşumu ve yeniden şekillenmeyi desteklemek amacıyla uygulanmaktadır. ${ }^{[2]}$ Avasküler nekrozda yeterli osteoprogenitör hücrenin olmaması iyileşmenin oluşmamasında önemli rol oynamaktadır. Çok yönlü MKH, farklı dokulara değişme potansiyeli olması nedeniyle nekrotik alanda yeniden kemik oluşumunu sağlamak için kullanılmaktadır. Kemik iliğinden elde edilen $\mathrm{MKH}, \mathrm{KD}$ kanalından dekompresyon yapılan nekrotik alana uygulanmaktadır. ${ }^{26]}$ Sen ve ark., 51 FBAVN hastalarını izole KD uygulanan ve KD-MKH uygulanan olmak üzere iki gruba ayırmışlardır. KD-MKH uygulanan grubun, MR, sağkalım ve klinik sonuçlarının izole $K D$ gruba göre daha üstün olduğu bildirilmiştir. Kemik ödemi olan, kalça skor değerleri düşük olan ve radyolojik değişiklikleri olan hastalarda sonuçların kötü olduğu görülmüştür. ${ }^{[27]}$ Gangji ve ark., KD ile kemik iliği aspiratı konsantrasyonu ile birlikte KD yapılan hastaları karşılaştırmışlar. KD ile birlikte kemik iliği aspiratı uygulanan hastalarda, şikayetlerde azalma ve hastalık ilerlemesinde yavaşlamanın diğer gruba göre belirgin üstün olduğu görülmüştür. ${ }^{[28]}$ iki farklı güncel sistemik analiz incelemesinde KD-MKH kombinasyonun, çökme öncesi erken evre FBAVN hastalarında hastalık progresyonunu yavaşlattığı, şikayetlerde azaltma sağladığını ve kalça artroplastisine dönüş oranını düşürdüğünü bildirmiştir. $^{[29,30]}$ Ayrıca yazarlar kanıt düzeyi daha yüksek çalışmalara ihtiyaç olduğunu bildirmişlerdir (Şekil 2).

\section{Kemik Morfojenik Protein}

Kemik morfojenik protein (KMP), osteogenezisi desteklemek amacıyla kullanılmaktadır ve kor dekompresyon ile birlikte uygulanabilir. Ayrıca femur baş ve boyun bileşke bölgesinde kaldırılan kortikal kemik alanından nekrotik kemikler temizlenip, kanama elde edildikten sonra da uygulanabilir. ${ }^{[1]}$ Seyler ve ark.'nın erken evre FBAVN olan 39 kalçayı içeren geriye dönük çalışmasında, 24 aylık takip sonrasında debridman, kemik grefti ve KMP uyguladıkları hastaların \%83,3'ünde ikincil cerrahi gerekmediğini belirtmişlerdir. ${ }^{[31]}$ Liebermann ve ark., erken evre FBAVN hastaların KD, fibula allogrefti ve KMP kombinasyonu yapılan 15 hastanın 43 aylık takip sonuçlarını yayımlamışlardır. Hastaların \%82'sinde hastalığın ilerlemediğini ve Harris kalça skorlarının ise 80 'in üzerinde olduğu belirtilmiştir. ${ }^{[32]}$ Bu çalışmalar göstermektedir ki KD ile birlikte kemik indüksiyonunu destekleyen materyaller kullanılması başarı şansını artırmaktadır. ${ }^{[31,32]}$

\section{Damarsız Kemik Greftleri}

Damarsız kemik greftleri çökme öncesi erken dönemde uygulanabilir. Teorik olarak damarsız kemik 

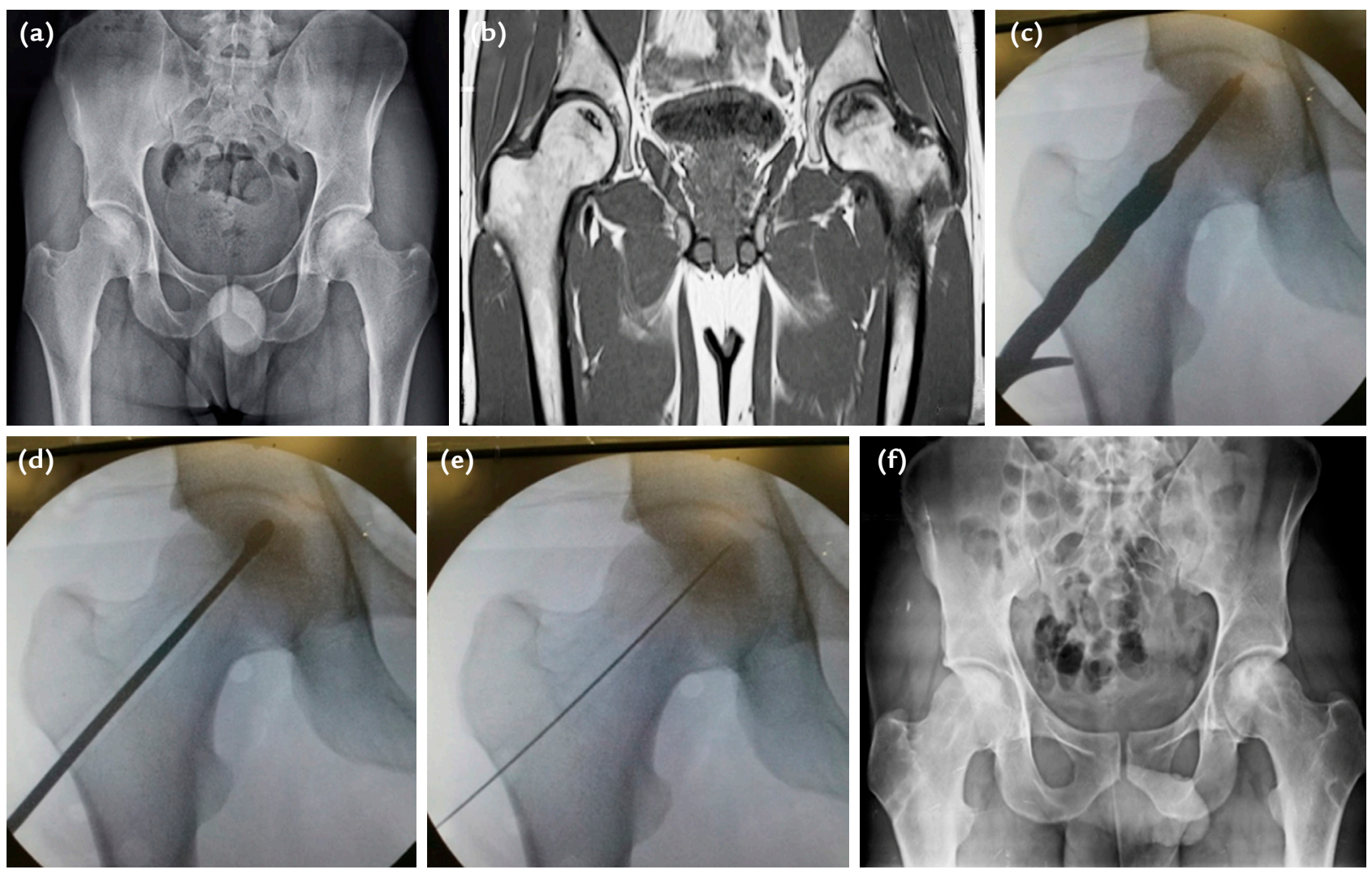

Şekil 2. a-f. Yirmi sekiz yaşında erkek hasta; Bilateral erken evre femur başında avasküler nekroz. Her iki kalça ameliyat öncesi radyografi (a); her iki kalça ameliyat öncesi MR (b); sağ kalça kor dekompresyon ve kemik iliği kaynaklı kök hücre uygulanması (c-e); her iki kalça ameliyat sonrası radyografi (f).

greftleri, nekrotik bölgenin temizlenerek, yerine femur başında subkondral bölgeyi desteklemek için uygulanır. Bu yöntemle kortikal ve kanselloz otogreft veya allogreftler kullanılabilir. ${ }^{[1]}$ Femur başına kemik greftleri; 1) Phemister tekniği, 2) Femur başından kıkırdak pencere (trapdoor) tekniği ve 3 ) Kortikal pencere (lightbulb) tekniği olmak üzere üç şekilde uygulanabilir. ${ }^{[2]}$

Phemister tekniğinde KD için açılan delikten iliak kanat, tibia veya fibula kortikal otogrefti uygulanmaktadır. Keizer ve ark., 65 hastanın 80 kalçasına çalışmaya almışlardır. Bir gruba KD ile birlikte tibia otogrefti, diğer gruba ise KD ile birlikte fibula allogrefti uygulamışlardır. Altı yıllık takip sonrasında KD ile birlikte tibia otogrefti uygulanan olguların sağkalım oranı $\% 70$, iken allogreft uygulanan grupta ise sağkalım oranı \%48 olarak bulunmuştur. ${ }^{[33]}$

Femur başından kıkırdak pencere açılarak uygulanan trapdoor tekniği kalça eklemi disloke edilerek kıkırdak kaldırılıp nekrotik kemik temizlendikten sonra, defektli alana greft yerleştirilmektedir. ${ }^{[34]}$ Genellikle ileri evre geniş nekrozu olan hastalarda uygulanmaktadır. Mont ve ark.'nın FICAT evre 3-4 olan hastalarda uyguladıkları bu tekniğin 56 aylık takip sonrası başarısını \%83 olarak bildirmişlerdir. ${ }^{[34]}$

Wang ve ark., Merle D'Aubignié tarafından tarif edilen iliak kanattan elde edilen spongiyoz greftin femur baş-boyun bileşkesinden açılan pencereden uygulanması olarak bilinen lightbulb (ampul) tekniğini kullanarak 110 kalçayı tedavi etmişlerdir. Dört yıllık takip sonrasında, femur başının \%15'inden az tutulum olan olgularda başarı oranı $\% 100, \% 15-30$ arasında tutulum olan olgularda başarı oranı $\% 93$ ve \%30'dan fazla tutulum olanlarda ise başarı oranı \%54 olarak bulunmuştur. ${ }^{[35]}$ Bu teknik ilgili çalışmalar sınırlı olmakla birlikte, genel olarak kabul edilen uygulama kriterleri olarak, femur başı tutulumun \%30'dan az ve çökmenin $2 \mathrm{~mm}$ 'den az olduğu hastalar olarak göze çarpmaktadır.

Damarsız kemik greftleme teknikleri ile ilgili kanıt seviyesi yüksek çalışmalara ihtiyaç vardır. Mevcut 
verilerde klinik sonuçların değişkenlik göstermesi nedeniyle optimal teknik arayışları devam etmektedir. Genel yaklaşım küçük-orta boyuttaki nekrozlarda kullanılabileceği yönündedir. ${ }^{[2]}$

\section{Damarlı Kemik Otogreftleri}

Damarlı kemik greftleri tekniğinde, vasküler yapısı korunan iliak kanat veya fibula $1 / 3$ orta diyafiz bölgesinden alınan kemik dokular kullanılmaktadır. ${ }^{[2]}$ Damarlı fibula otogreft tekniğinde, fibula orta $1 / 3$ diyafiz ve besleyici arter kullanılır. Alınan fibula, besleyici arter olan femoral arterin lateral sirkümfleks dalı ile anostomoz edilir. Alınan fibula grefti, KD için açılan delik içine yerleştirilir ve tespit edilir ${ }^{[1]}$. Aldridge ve ark., 2007 yılındaki çalışmalarında, femur başının yarısından azını tutan, eklem deplasmanın $3 \mathrm{~mm}$ 'den az olduğu ve kemik çökmenin olmadığı FBAVN olguları için damarlı fibula otogreft kullanımını önermişlerdir. ${ }^{[36]}$ Ayrıca KD tekniğinin başarısız olduğu, ARCO sınıflamasına göre evre 1-2 ve ARCO evre 3 ancak küçük boyutta, minimal çökme olan olgularda da uygulanabilir. ${ }^{[1]}$

Yoo ve ark., 135 hastanın 151 kalçasına uyguladıkları damarlı fibula otogrefti tekniğinin yaklaşık 14 yıllık takip sonuçlarını yayımlamışlar, Harris kalça skorlarının 72'den 88'e yükseldiğini ve hastaların yaklaşık \%10,5'inde kalça artroplastisine dönüşüm olduğunu bildirmişlerdir. Bu tekniğin hastalık progresyonunu yavaşlayan ve kalça fonksiyonlarını iyileştiren bir yöntem olduğunu vurgulamışlardır. Ayrıca damarsız kemik greftlerine daha üstün olduğu bildirilmiştir. Ancak hastanın yaşı, lezyon yerleşimi ve boyutu greftin hayatta kalmasını etkileyen faktörler olarak göze çarpmıştır. Mikrocerrahi işlem gerektirmesi ve peroneal sinir hasarı olması tekniğin olumsuz yanları olarak görülmektedir. ${ }^{[37]}$

\section{Proksimal Femoral Osteotomiler}

FBAVN tedavisinde proksimal femoral osteotomilerin (PFO) hedefi, femur başındaki nekrotik alanı yükten kurtarmak suretiyle, kemik içi basıncı düşürmek ve kanlanmayı korumaktır. Nekrotik alanın yerleşimin göre farklı PFO'lar tanımlanmıştır. PFO'lar genel olarak intertrokanterik (valgus-fleksiyon ve varus) ve transtrokanterik (rotasyonel) olarak ikiye ayrılır. ${ }^{[1]}$

Femur başında anterolateral bölge nekrozlarında; valgus ve fleksiyon, medial bölge nekrozlarında varus osteotomileri uygulanabilir. ${ }^{[38]}$ Scher ve ark., anterolateral nekrozu olan 48 olguya uyguladıkları valgusfleksiyon PFO sonrası 5 yıllık takiplerinde, kalça fonksiyonlarında iyileşme ve $\% 87$ hastada artroplasti tedavisinin gerekmediği bildirilmiştir. ${ }^{[39]}$ Mont ve ark.'nın
ARCO evre 2-3 olan olgulara uyguladıkları varus osteotomisinin 11 yıllık sonuçlarında \%76 iyi sonuç elde etmişlerdir. ${ }^{[38]}$

Transtrokanterik rotasyonal PFO (TRPFO), özellikle femur başının anterosuperior lezyonları için önerilmektedir. Sugioka ve ark., Japon hastalarda femur başının korunma oranının 18 yıla kadar olan takiplerinde \%70-80 olduğunu bildirmişlerdir. ${ }^{[40]}$ Fakat Asya kökenli olmayan hastalarda TRPFO'sinin 5 yıllık başarı oranı \%40'lardan daha az bulunmuştur. ${ }^{[41]}$ Asya kökenli hastaların kapsül yapısı daha gevşek olduğu için TRPFO sonuçlarının daha başarılı olduğu düşünülmektedir. Chughtai ve ark., PFO'da uzun süre steroid kullanmayan, 40 yaş altı ve vücud kitle indeksi $25 \mathrm{~kg} /$ $\mathrm{m}^{2}$ 'nin altında olan hastalarda başarı oranının yüksek olduğu bildirilmiştir. ${ }^{[42]}$

PFO'lar 40 yaş altı genç, ARCO evre 2-3, Kerboul açısı $200^{\circ}$ 'nin altında ve asetabular tutulumu olmayan ve normal kalça eklem hareketine sahip olan hastalar için önerilmektedir. Uygun hasta seçimi ile uygulanan PFO sonuçları, kalça artroplastisi sonuçları ile benzerlik göstermektedir. Ancak PFO sonrası kalça artroplastisi yapılan hastalarda kanama miktarı, cerrahi süre ve femur diyafiz kırık riski artmaktadır. ${ }^{[1]}$

\section{Gözenekli Tantalum Çubuk}

Bu yöntemle KD ile açılan kanal içine femur başına destek olması amacıyla tantalum çubuk yerleştirilmesi amacı taşımaktadır. Ayrıca bu teknikle MKH veya kemik grefti de kombine edilebilir. ${ }^{[1]}$ Pakos ve ark., çökme öncesi dönemdeki 58 kalçaya gözenekli tantalum çubuk (GTÇ) ile birlikte MKH uygulamışlardır. Hastaların \%88'sinde hastalık progresyonunda ilerleme olmamıştır ve kalça artroplastisine dönüşüm oranı \%6'dır. ${ }^{[43]}$ Zhang ve ark.'nın güncel meta-analizinde, GTÇ tedavisi uygulanan hastaların kalça skorlarında belirgin iyileşme ve kalça sağkalım oranında artış görülmüştür. Ancak standart protokollerin olmaması ve kalça artroplastisine dönüşümde zorluk içerebileceği bildirilmiştir. ${ }^{[44]}$ Tanzer ve ark., 113 kalçaya uygulanan GTÇ hastalarının 17'sinde (\%15) başarısızlık olduğu bildirilmiştir. Başarısız olarak çıkarılan implantlarda yetersiz kemik büyümesi görülmüştür. ${ }^{[45]} \mathrm{Ma}$ ve ark.'nın 104 kalçaya GTÇ ile birlikte kemik grefti tekniğini uygulamışlar ve hastaların 42 aylık takibinde başarı oranlarını \%52,9 olarak bildirmişlerdir. Özellikle ARCO evre 3 lezyonlarda bu yöntemin kullanılmaması gerektiğini bildirmişlerdir. ${ }^{[46]}$

\section{HemiCAP Yüzey değiştirme}

HemiCAP yüzey değiştirme asetabulum tutulumunun olmadığı ve femur başta ileri evre kondral hasarın 

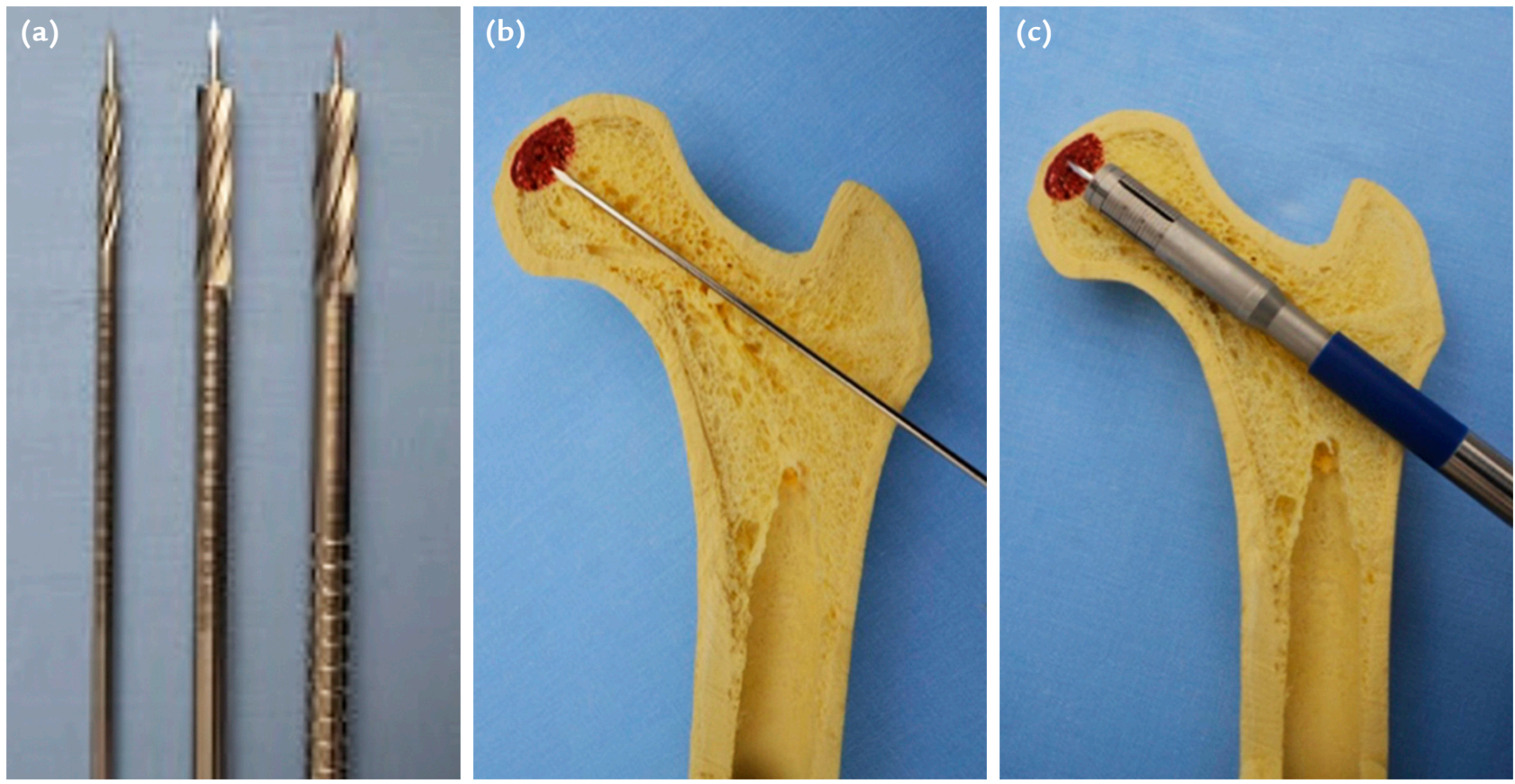

Şekil 3. a-c. Kor dekompresyon için kullanılan; kanüle, ancak içleri dolu, farklı çaplardaki matkap uçları (a); femur baş AVN bölgesine Kirshner teli yollanması (b); Kirshner teli üzerinden, modifiye edilmiş içi boş mozaikplasti greft alıcısının nekrotik alana kadar gönderilmesi (c).

olan hastalara için uygulanabilecek bir yöntemdir. ${ }^{[2]}$ Ancak metal yüzeyli implantın zaman içinde femur başı ve asetabulumda ilerleyici artrozik değişikler yaratması bu yöntemin en önemli olumsuz yönüdür. ${ }^{[2,42]}$ Olgu serisi şeklinde yapılan bir çalışmada FBAVN hastalarında kısa dönem takipte mükemmel sonuçlar bildirilmiş olsa da devam eden ağrı, eklemde artroz ve implant cevresi kırıkları içeren yüksek komplikasyon oranları da verilmiştir. ${ }^{[47]} \mathrm{Bu}$ implantları geleceği belirsizdir ve yüksek komplikasyon oranlarına sahip olması günümüzde bu tedavi yönteminin kullanılırlığı azalmıştır.

\section{Femur Başını Koruyan Diğer Teknikler}

Femur başını korumak için yukarıdaki tekniklerin haricinde uygulanan farklı yöntemler de tanımlanmıştır. KD ile birlikte uygulanan MKH'nin uygulandığı subkondral alanda kalması ve femur boynunu desteklemesi tedavi başarısını doğrudan etkileyebilir. $\mathrm{Bu}$ nedenle hem MKH'nin geri kaçmasını önlemek hem de oyulan femur boynunu desteklemek için KD oyma işlemi sırasında femur başındaki nekrotik alana ulaşana kadar elde edilen sağlıklı kemik veya iliak kanattan alınacak otogreft kullanılabilir. Femur boynundan nekrotik alana KD işlemi için yollanan Kirshner teli üzerinden $8-10 \mathrm{~mm}$ oyucular ile sadece lateral korteks oyulur. Ardından oyucu çapına uygun, modifiye edilmiş içi boş ve yuvarlak mozaikplasti greft alıcısı açılan delikten lezyon alanına kadar çakılır ve döndürülerek çıkarılır. Kanül içindeki spongiyoz greft dışarı alınır. Nekrotik alan skopi kontrolü altında, ucu açılı uzun saplı küretlerle temizlenir. MKH uygulandıktan sonra, oluşturulan kanaldan çıkartılan spongioz yapıdaki sağlam greft, giriş deliğinden femur boynundaki çıkartıldığı tünele geri çakılır. Böylece hem MKH'nin alanda kalması sağlanır, hem de femur boynu desteklenmiş olur (Şekil 3). ${ }^{[48]}$

\section{KALÇA ARTROPLASTiSi}

Femur başı koruyucu konservatif veya cerrahi tedaviye rağmen FBAVN hastalarının bir kısmında femur başında çökme veya artroz görüldüğü durumlarda total kalça artroplastisi (TKA) tek cerrahisi seçenek olarak göze çarpmaktadır (Şekil 4). TKA'si kalça eklem hareket kabiliyetini artıran ve ağrıyı ortadan kaldıran başarılı bir cerrahi yöntemdir. ${ }^{[49]}$ Tüm total kalça protezi yapılan hastaların yaklaşık \%2,8-6'sı femur başı avasküler nekrozuna bağlı yapıldığı bilinmektedir. ${ }^{[1]}$ Johannson ve ark.'nın yaptığı sistematik analizde 3.277 hastaya FBAVN nedeniyle TKA yapılan hastaların 6 yıllık takip sonrası sağkalım \%97 oranında bulunmuştur ve elde edilen bu sonuçlar primer koksartroz nedeniyle artroplasti yapılan hastalarla benzer bulunmuştur. ${ }^{[50]}$ 

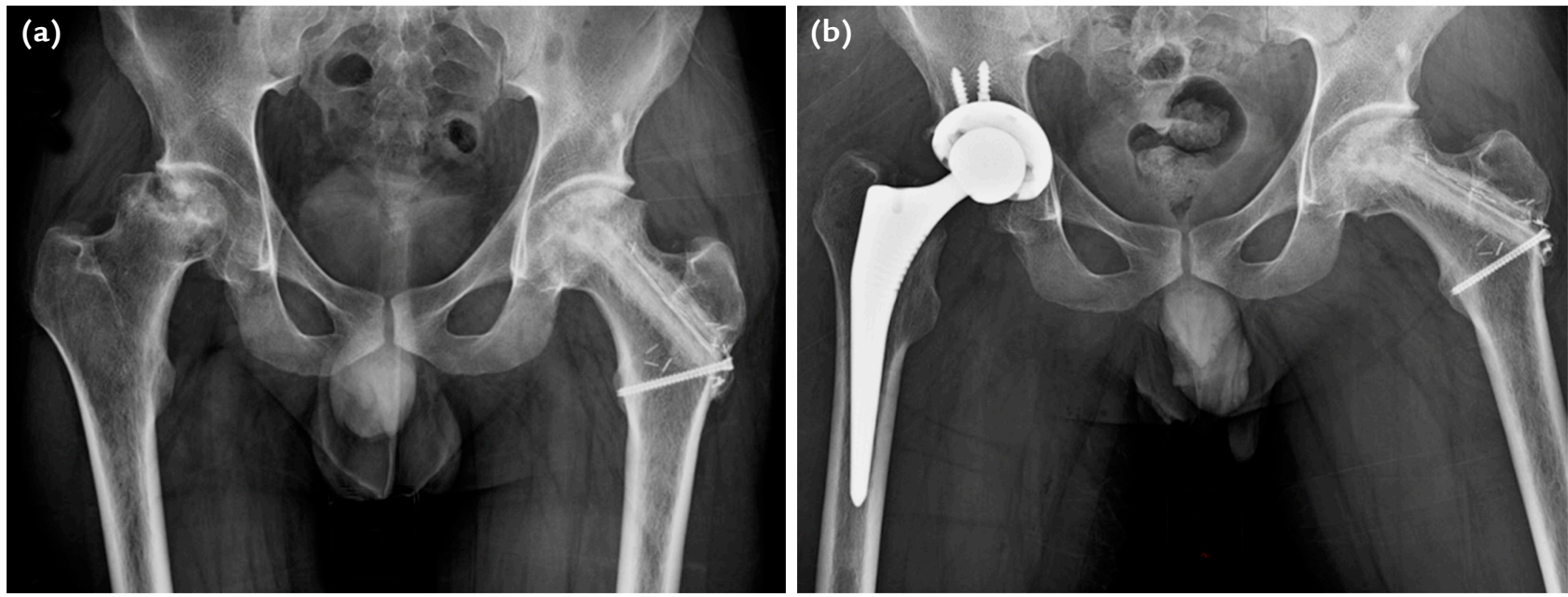

Şekil 4. a, b. Yirmi altı yaşında hasta; bilateral kalça avasküler nekrozu. Sağ kalçada AVN ve daha önce sol kalçaya damarlı fibula grefti uygulanmış (a); daha sonra sağ kalçaya total kalça protezi uygulandı (b).

İdiopatik veya sistematik lupus eritamozusa bağIı avasküler nekrozlu hastalara göre, orak hücreli anemi, Gaucher hastalığı ve transplantasyona bağlı FBAVN olan hastalarda uygulanan TKA'larda yüksek revizyon oranı bulunmuştur. ${ }^{[51]}$ Kim ve ark., 148 FBAVN hastasına uyguladıkları TKA'nın 17 yıllık sonuçlarını değerlendirmişlerdir. Femoral stem sağkalım oranı \%98 oranında iken, sementsiz asetabular komponent sağkalım oranı \%85 oranında bulunmuştur. ${ }^{[52]}$ En sık revizyon sebebi olarak asetabular komponent gevşemesi olarak bildirilmiştir. Primer koksartrozda titanyum veya tantalum yüksek porozlu asetabular komponentlerin sonuçlarının mükemmel olması, FBAVN'ye bağlı TKA uygulanan hastalar için umut verici olabilir. ${ }^{[53]}$

FBAVN nedeniyle TKA uygulanan genç hastalar için seramik-seramik veya seramik yüksek çapraz bağlı polietilen, yüzey seçiminde öne çıkmaktadır. Kim ve ark.'nın seramik baş-yüksek çapraz bağlı polietilen kap kullanarak uyguladıkları TKA olgularında enfeksiyon hariç 8,5 yıllık takip sonrası sağkalım oranını \%100 olarak bulmuşlardır. ${ }^{[54]}$ Başka bir çalışmada asetabular çok yüksek çapraz bağlı polietilen ile krom-kobalt baş kullanılarak uygulanan sementsiz TKA hastalarında 5 yılık sağkalım oranını \%100 olarak belirtmişlerdir. ${ }^{[55]}$ Feng ve ark.'nın FBAVN nedeniyle TKA uyguladıkları hastaları "seramik - seramik yüzey" ve "seramik - çok yüksek çapraz bağlı polietilen yüzey" olmak üzere iki gruba ayırmışlardır. Ortalama 7 yıllık takibi olan hastaların klinik sonuçları benzer iken seramik seramik yüzeyde aşınmanın daha az olduğunu bildirmişlerdir. ${ }^{[56]}$

\section{SONUÇ}

FBAVN fizyopatolojisini açılamaya çalışan farklı teoriler öne süren veya birden çok faktör üzerinde duran çalışmalar mevcut olmakla birlikte henüz cevaplanamayan birçok soru mevcuttur. FBAVN tedavisine karar verir iken hastanın yaşı, avasküler nekroz etiyolojisi, lezyonun boyutu, femur başında çökme durumu ve eklemdeki artrozik değişiklikler gibi birçok faktör etkilidir. Özellikle çökme öncesi dönemde eklem koruyucu veya femur baş koruyucu cerrahiler uygulanmalıdır. Çökme öncesi dönemdeki asemptomatik hastalar konservatif yakın takip ile gözlenebilir. Semptomatik çökme öncesi dönemde olan ve küçük alanı içine alan nekrozu olan olgularda KD ile birlikte hücresel tedaviler kombine edilebilmektedir. Çökme öncesi küçük-orta boyutta nekrozu olan olgularda damarlı veya damarsız kemik greftleri uygulanabileceği gibi PFO'larda tedavi seçenekleri arasında yer almaktadır. Femur başı çökme sonrası dönemde ise ideal tedavi seçeneği total kalça artroplastisi olarak görülmektedir. Ancak güncel literatürde ideal FBAVN tedavisi arayışları devam etmektedir.

\section{KAYNAKLAR}

1. Petek D, Hannouche D, Suva D. Osteonecrosis of the femoral head: pathophysiology and current concepts of treatment. EFORT Open Rev 2019;4(3):85-97. Crossref

2. Atilla B, Bakırcıoğlu S, Shope AJ, Parvizi J. Joint-preserving procedures for osteonecrosis of the femoral head. EFORT Open Rev 2020;4(12):647-58. Crossref

3. Yoon BH, Kim TY, Shin IS, Lee HY, Lee YJ, Koo KH. Alcohol intake and the risk of osteo-necrosis of the femoral head in Japanese populations: a dose-response meta-analysis of case-control studies. Clin Rheumatol 2017;36(11):2517-24. Crossref 
4. Zhang NF, Li ZR, Wei HY, Liu ZH, Hernigou P. Steroid-induced osteonecrosis: the number of lesions is related to the dosage. J Bone Joint Surg Br 2008;90-B(9):1239-43. Crossref

5. Conway WF, Totty WG, McEnery KW. CT and MR imaging of the hip. Radiology 1996;198(2):297-307. Crossref

6. Dasa V, Adbel-Nabi H, Anders MJ, Mihalko WM. F-18 fluoride positron emission tomography of the hip for osteonecrosis. Clin Orthop Relat Res 2008;466(5):1081-6. Crossref

7. Kerboul M, Thomine J, Postel M, Merle d'Aubigné R. The conservative surgical treatment of idiopathic aseptic necrosis of the femoral head. J Bone Joint Surg Br 1974;56-B(2):2916. Crossref

8. Ha YC, Jung WH, Kim JR, Seong NH, Kim SY, Koo KH. Prediction of collapse in femoral head osteonecrosis: a modified Kerboul method with use of magnetic resonance images. J Bone Joint Surg Am 2006;88-A(Suppl 3):35-40. Crossref

9. Carli A, Albers A, Séguin C, Harvey EJ. The medical and surgical treatment of ARCO Stage-I and II osteonecrosis of the femoral head: a critical analysis review. JBJS Rev 2014;2(2):1-10. Crossref

10. Mont MA, Carbone JJ, Fairbank AC. Core decompression versus nonoperative management for osteonecrosis of the hip. Clin Orthop Relat Res 1996;324:169-78. Crossref

11. Neumayr LD, Aguilar C, Earles AN, Jergesen HE, Haberkern CM, Kammen BF, Nancarrow PA, Padua E, Milet M, Stulberg BN, Williams RA, Orringer EP, Graber N, Robertson SM, Vichinsky EP; National Osteonecrosis Trial in Sickle Cell Anemia Study Group. Physical therapy alone compared with core decompression and physical therapy for femoral head osteonecrosis in sickle cell disease. Results of a multicenter study at a mean of three years after treatment. J Bone Joint Surg Am 2006;88-A(12):2573-82. Crossref

12. Villa JC, Husain S, van der List JP, Gianakos A, Lane JM. Treatment of precollapse stages of osteonecrosis of the femoral head: a systematic review of randomized control trials. HSS J 2016;12(3):261-71. Crossref

13. Ajmal M, Matas AJ, Kuskowski M, Cheng EY. Does statin usage reduce the risk of corticos-teroid-related osteonecrosis in renal transplant population? Orthop Clin North Am 2009;40(2):235-9. Crossref

14. Glueck CJ, Freiberg RA, Sieve L, Wang P. Enoxaparin prevents progression of stages I and II osteonecrosis of the hip. Clin Orthop Relat Res 2005;(435):164-70. Crossref

15. Disch AC, Matziolis G, Perka C. The management of necrosisassociated and idiopathic bone-marrow oedema of the proximal femur by intravenous iloprost. J Bone Joint Surg $\mathrm{Br}$ 2005;87-B(4):560-4. Crossref

16. Camporesi EM, Vezzani G, Bosco G, Mangar D, Bernasek TL. Hyperbaric oxygen therapy in femoral head necrosis. J Arthroplasty 2010;25(6):118-23. Crossref

17. Uzun G, Mutluoglu M, Ersen O, Yildiz S. Hyperbaric oxygen therapy in the treatment of os-teonecrosis of the femoral head: a review of the current literature. Undersea Hyperb Med 2016;43(3):189-99. https://pubmed.ncbi.nlm.nih. gov/27416686/

18. Lai KA, Shen WJ, Yang CY, Shao CJ, Hsu JT, Lin RM. The use of alendronate to prevent early collapse of the femoral head in patients with nontraumatic osteonecrosis. A randomized clinical study. J Bone Joint Surg Am 2005;87-A(10):2155-9. Crossref

19. Chen $\mathrm{CH}$, Chang JK, Lai KA, Hou SM, Chang $\mathrm{CH}$, Wang G). Alendronate in the prevention of collapse of the femoral head in nontraumatic osteonecrosis: a two-year multicenter, prospective, randomized, double-blind, placebo-controlled study. Arthritis Rheum 2012;64(5):1572-8. Crossref
20. Li D, Yang Z, Wei Z, Kang P. Efficacy of bisphosphonates in the treatment of femoral head osteonecrosis: A PRISMAcompliant meta-analysis of animal studies and clinical trials. Sci Rep 2018;8(1):1450. Crossref

21. Russo S, Sadile F, Esposito R, Mosillo G, Aitanti E, Busco G, Jen Wang C. Italian experience on use of E. S. W. therapy for avascular necrosis of femoral head. Int J Surg 2015;24:18890. Crossref

22. Alves EM, Angrisani AT, Santiago MB. The use of extracorporeal shock waves in the treatment of osteonecrosis of the femoral head: a systematic review. Clin Rheumatol 2009;28(11):1247-51. Crossref

23. Mont MA, Ragland PS, Etienne G. Core decompression of the femoral head for osteonecrosis using percutaneous multiple small-diameter drilling. Clin Orthop Relat Res 2004;429:1318. Crossref

24. Ficat RP. Idiopathic bone necrosis of the femoral head. Early diagnosis and treatment. J Bone Joint Surg $\mathrm{Br}$ 1985;67$B(1): 3-9$. Crossref

25. Tripathy SK, Goyal T, Sen RK. Management of femoral head osteonecrosis: current concepts. Indian J Orthop 2015;49(1):28-45. Crossref

26. Hernigou P, Beaujean F. Treatment of osteonecrosis with autologous bone marrow grafting. Clin Orthop Relat Res 2002;405:14-23. Crossref

27. Sen RK, Tripathy SK, Aggarwal S, Marwaha N, Sharma RR, Khandelwal N. Early results of core decompression and autologous bone marrow mononuclear cells instillation in femoral head osteonecrosis: a randomized control study. J Arthroplasty 2012;27(5):679-86. Crossref

28. Gangji V, De Maertelaer V, Hauzeur JP. Autologous bone marrow cell implantation in the treatment of non-traumatic osteonecrosis of the femoral head: five year follow-up of a prospective controlled study. Bone 2011;49(5):1005-9. Crossref

29. Papakostidis C, Tosounidis TH, Jones E, Giannoudis PV. The role of "cell therapy" in osteonecrosis of the femoral head. A systematic review of the literature and meta-analysis of 7 studies. Acta Orthop 2016;87(1):72-8. Crossref

30. Piuzzi NS, Chahla J, Jiandong $H$, Chughtai M, LaPrade RF, Mont MA, Muschler GF, Pascual-Garrido C. Analysis of cell therapies used in clinical trials for the treatment of osteonecrosis of the femoral head: a systematic review of the literature. J Arthroplasty 2017;32(8):2612-8. Crossref

31. Seyler TM, Marker DR, Ulrich SD, Fatscher T, Mont MA. Nonvascularized bone grafting defers joint arthroplasty in hip osteonecrosis. Clin Orthop Relat Res 2008;466(5):1125-32. Crossref

32. Lieberman JR, Conduah A, Urist MR. Treatment of osteonecrosis of the femoral head with core decompression and human bone morphogenetic protein. Clin Orthop Relat Res 2004;429:139-45. Crossref

33. Keizer SB, Kock NB, Dijkstra PD, Taminiau AH, Nelissen RG. Treatment of avascular necro-sis of the hip by a nonvascularised cortical graft. J Bone Joint Surg $\mathrm{Br}$ 2006;88$\mathrm{B}(4): 460-6$. Crossref

34. Mont MA, Einhorn TA, Sponseller PD, Hungerford DS. The trapdoor procedure using autogenous cortical and cancellous bone grafts for osteonecrosis of the femoral head. J Bone Joint Surg Br 1998;80(1):56-62. Crossref

35. Wang BL, Sun W, Shi ZC, Zhang NF. Yue DB, Guo WS, Shi $\mathrm{SH}$, Li ZR. Treatment of non-traumatic osteonecrosis of the femoral head using bone impaction grafting through a femoral neck window. Int Orthop 2010;34(5):635-9. Crossref 
36. Aldridge JM III, UrbaniakJR. Avascular necrosis of the femoral head: role of vascularized bone grafts. Orthop Clin North Am 2007;38(1):13-22. Crossref

37. Yoo MC, Kim KI, Hahn CS, Parvizi J. Long-term followup of vascularized fibular grafting for femoral head necrosis. Clin Orthop Relat Res 2008;466(5):1133-40. Crossref

38. Mont MA, Fairbank AC, Krackow KA, Hungerford DS. Corrective osteotomy for osteonecrosis of the femoral head. J Bone Joint Surg Am 1996;78-A(7):1032-8. Crossref

39. Scher MA, Jakim I. Late follow-up of femoral head avascular necrosis managed by intertrochanteric osteotomy \& bone grafting. Acta Orthop Belg 1999;65 Suppl 1:73-7. https:// pubmed.ncbi.nlm.nih.gov/10084222/

40. Sugioka $Y$, Hotokebuchi $T$, Tsutsui H. Transtrochanteric anterior rotational osteotomy for idiopathic and steroidinduced necrosis of the femoral head. Indicationsand long-term results. Clin Orthop Relat Res 1992;(277):111-20. https:// journals.Iww.com/clinorthop/Abstract/1992/04000/ Transtrochanteric_Anterior_Rotational_Osteotomy.13.aspx

41. Marker DR, Seyler TM, McGrath MS, Delanois RE, Ulrich $\mathrm{SD}$, Mont MA. Treatment of early stage osteonecrosis of the femoral head. J Bone Joint Surg Am 2008;90-A Suppl 4:17587. Crossref

42. Chughtai M, Piuzzi NS, Khlopas A, Jones LC, Goodman SB, Mont MA. An evidence-based guide to the treatment of osteonecrosis of the femoral head. Bone Joint J 2017;99$\mathrm{B}(10): 1267-79$. Crossref

43. Pakos EE, Megas P, Paschos NK, Syggelos SA, Kouzelis A, Georgiadis G, Xenakis TA. Modified porous tantalum rod technique for the treatment of femoral head osteonecrosis. World j Orthop 2015;6(10):829-37. Crossref

44. Zhang Y, Li L, Shi ZJ, Wang J, Li ZH. Porous tantalum rod implant is an effective and safe choice for early-stage femoral head necrosis: a meta-analysis of clinical trials. Eur J Orthop Surg Traumatol 2013;23:211-7. Crossref

45. Tanzer M, Bobyn JD, Krygier JJ, Karabasz D. Histopathologic retrieval analysis of clinically failed porous tantalum osteonecrosis implants. J Bone Joint Surg Am 2008;90(6):1282-9. Crossref

46. Ma J, Sun W, Gao F, Guo W, Wang Y, Li Z. Porous tantalum implant in treating osteonecrosis of the femoral head: still a viable option? Sci Rep 2016;6(1):28227. Crossref

47. Banerjee S, Issa K, Pivec R, Kapadia BH, Khanuja HS, Mont MA. Osteonecrosis of the hip: treatment options and outcomes. Orthop Clin North Am 2013;44(4):463-76. Crossref
48. Esenkaya i. Femur bașı ve diz eklemi çevresi avasküler nekrozunda subkondral bölgenin boşaltılması ve greftlenmesi için kanüle oyucuların kullanılması. 28. Ulusal Türk Ortopedi ve Travmatoloji Kongresi "Uluslararası katılımlı", 2018. AOTT, Supplementum-I, Kongre Bildiri Özetleri Özel Eki, Poster Bildiri (P 240); 2018. s.198. https://www.aott.org.tr/ Content/files/sayilar/665/AOTT_52_S1.pdf

49. Issa K, Pivec R, Kapadia BH, Banerjee S, Mont MA. Osteonecrosis of the femoral head: the total hip replacement solution. Bone Joint J 2013;95-B(11 Suppl A):46-50. Crossref

50. Johannson HR, Zywiel MG, Marker DR, Jones CL, McGrath MS, Mont MA. Osteonecrosis is not a predictor of poor outcomes in primary total hip arthroplasty: a systematic literature review. Int Orthop 2011;35(4):465-73. Crossref

51. Issa K, Naziri Q, Rasquinha VJ, Tatevossian $\mathrm{T}$, Kapadia $\mathrm{BH}$, Mont MA. Outcomes of primary total hip arthroplasty insystemic lupus erythematosus with a proximally-coated cementless stem. J Arthroplasty 2013;28(9):1663-6. Crossref

52. Kim YH, Kim JS, Park JW, Joo JH. Contemporary total hip arthroplasty with and without cement in patients with osteonecrosis of the femoral head: a concise followup, at an average of seventeen years, of a previous report. J Bone and Joint Surg Am 2011;93-A(19):1806-10. Crossref

53. Macheras G, Kateros K, Kostakos A, Koutsostathis $\mathrm{S}$, Danomaras D, Papagelopoulos PJ. Eight to ten year clinical and radiographic outco-me of a porous tantalum monoblock acetabular component. J Arthroplasty 2009;24(5):705-9. Crossref

54. Kim YH, Choi Y, Kim JS. Cementless total hip arthroplasty with alumina-on-highly cross-linked polyethylene bearing in young patients with femoral head osteonecrosis. J Arthroplasty 2011;26(2):218-23. Crossref

55. Min BW, Lee KJ, Song KS, Bae KC, Cho CH. Highly crosslinked polyethylene in total hip arthroplasty for osteonecrosis of the femoral head: a minimum 5-year follow-up study. J Arthroplasty 2013;28(3):526-30. Crossref

56. Feng B, Ren Y, Cao S, Lin J, Jin J, Qian W, Weng X. Comparison of ceramic-on-ceramic bearing vs ceramic-on-highly crosslinked polyethylene-bearing surfaces in total hip arthroplasty for avascular necrosis of femoral head: a prospective cohort study with a mid-term follow-up. J Orthop Surg Res 2019;14(1):388. Crossref 